\title{
(NOTA ADICIONAL)
}

Respecto al poema judeo-español marroquí que dimos a conocer en Celestinesca, 2:1 (mayo, 1978), 3-5, conviene tener en cuenta una coinci-. dencia verbal que nos proporcionan dos versiones marroquíes inéditas. Un texto tangerino de la colección Menéndez Pidal termina con los versos:

\section{hasta que estaba más muerto}

que su abuelo.

[S. G. Arnistead et al., El romoncero judeo-español en el Archivo Menéndez Pidal, 3 tomos, Madrid: Cátedra-Seminario Menéndez Pidal, 1978, núm. R11.1.]

Aún mejor es la lectura que se encuentra en el manuscrito tetuaní de Luna Bennaim (núm. 52):

\section{Más muerto está \\ que mi abuelo.}

La canción sefardí refleja, claro está, las palabras de Sosia (LC, XIX): "iSeñor, señor! iA esotra puerta! iTan muerto es como mi abuelo! iOh gran desventura!" [ed. D. S. Severin, Madrid: Alianza, 1971, pág. 224]. El detalle confirma, si falta hacía, el evidente origen del poema sefardí en la obra de Rojas. [S. G. A. y J. H. H.]
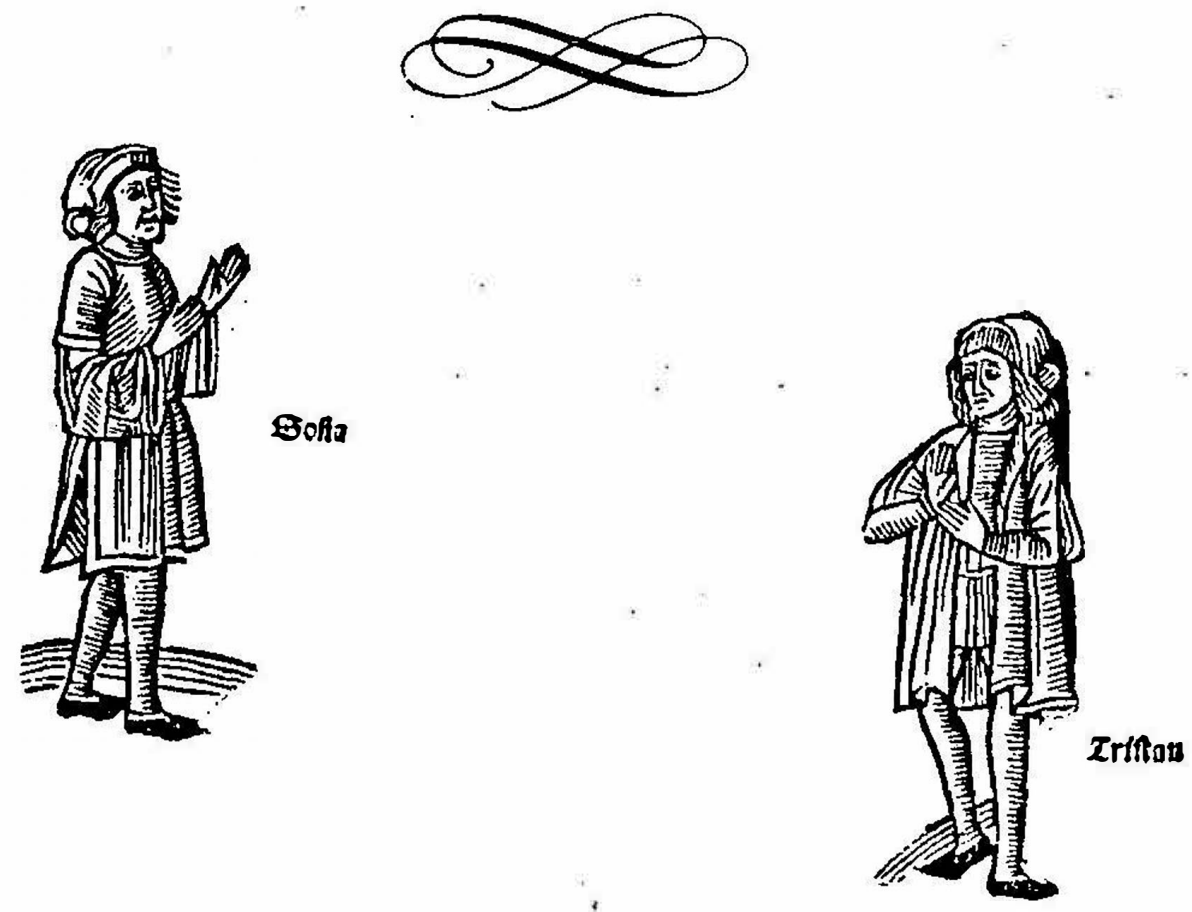